\title{
PENGEMBANGAN SISTEM INFORMASI REGISTRASI MAHASISWA BARU DENGAN METODE ANALISIS GUGUS KENDALI MUTU
}

\author{
Santo Wijaya ${ }^{1}$, Marta Hayu R.S.R. Sari ${ }^{2}$, Adian Wihariono Putera ${ }^{3}$ \\ ${ }^{1}$ Program Studi Teknik Komputer, Politeknik Meta Industri Cikarang, Bekasi, Jawa Barat \\ ${ }^{2}$ Program Studi Teknik Industri, Politeknik Meta Industri Cikarang, Bekasi, Jawa Barat \\ ${ }^{3}$ Departmen Marketing \& Humas, Politeknik Meta Industri Cikarang, Bekasi, Jawa Barat
}

email: santo.wijaya@politeknikmeta.ac.id ${ }^{1}$, marta@politeknikmeta.ac.id ${ }^{2}$, adian.wp@politeknikmeta.ac.id ${ }^{3}$

\begin{abstract}
Abstrak
Pendidikan sebagai industri produk dan jasa berbasis ilmu pengetahuan dan keterampilan menghadapi persaingan yang semakin kompetitif dengan banyaknya institusi baik dalam dan luar negeri yang operasional di Indonesia. Untuk meningkatkan daya saing, maka utilisasi teknologi informasi khususnya di era revolusi industri 4.0 menjadi kunci penting. Penelitian ini bertujuan untuk mengembangkan Sistem Informasi Registrasi Mahasiswa Baru (SIRMB) menggunakan kerangka open-source web-based application serta integrasinya dengan teknologi Application Programming Interface (API) Bank BNI menjadikan layanan administrasi yang terotomasi sebagai perancangan solusinya. Proses identifikasi masalah sampai perancangan solusi SIRMB menggunakan metode analisis gugus kendali mutu (QCC) dengan pendekatan Plan-Do-Check-Action (PDCA) sehingga menjamin perbaikan yang berkesinambungan. Penelitian ini berkontribusi terhadap perbaikan $76.9 \%$ terhadap proses kerja dengan eliminasi proses kerja manual registrasi mahasiswa baru, sehingga memberikan peningkatan kualitas layanan dan peningkatan produktivitas secara keseluruhan.
\end{abstract}

Kata kunci: industri pendidikan, layanan mahasiswa, sistem informasi, API, QCC, PDCA.

\begin{abstract}
Education as a product and service industry based on knowledge and skills is facing increasingly competitive competition with many domestic and foreign institutions operating in Indonesia. To increase competitiveness, the utilization of information technology, especially in the era of the industrial revolution 4.0, is an important key. This study aims to develop a New Student Registration Information System (SIRMB) using an open-source web-based application framework and its integration with Bank BNI's Application Programming Interface (API) technology to create automated administrative services as a designed solution. The problem identification process until the design of the SIRMB solution uses Quality Control Circle (QCC) analysis method with the Plan-Do-Check-Action (PDCA) approach so as to ensure continuous improvement. This research contributes to the improvement of $76.9 \%$ of the work process by eliminating the manual work process of new student registration, thereby providing an increase in service quality and an increase in overall productivity.
\end{abstract}

Keywords : education industry, student service, information system, API, QCC, PDCA

Diterima Redaksi: 4-12-2021 | Selesai Revisi: 28-12-2021 | Diterbitkan Online: 31-12-2021 DOI: https://doi.org/10.23887/janapati.v10i3.41763

\section{PENDAHULUAN}

Pendidikan adalah suatu usaha sadar dalam rangka menanamkan daya-daya kemampuan, baik yang berhubungan dengan pengalaman kognitif, afektif maupun psikomotorik yang dimiliki oleh seorang individu [1]. Pendidikan dapat dipandang sebagai sebuah industri produk dan jasa berbasis ilmu pengetahuan dan keterampilan karena organisasi pendidikan bertanggung jawab kepada pemakai jasanya yakni masyarakat melalui produk yang dihasilkan. Kualitas produk diukur dari bisnis proses dengan perencanaan, analisis, dan kontrol yang ketat [2]. Berdasarkan data [3] pada tahun 2021, jumlah Perguruan Tinggi (PT) khususnya di Jawa Barat mencapai 581 PT. Semakin banyaknya PT maka semakin tinggi tingkat persaingan sehingga setiap lembaga PT dituntut untuk menghadapi iklim kompetitif tersebut [4]. Salah satu strategi membangun keunggulan bersaing adalah 
Tabel 1. Evaluasi Proses Bisnis

\begin{tabular}{clccc}
\hline No & Proses Bisnis & Digitalisasi & Faktor Resiko & $\begin{array}{c}\text { Urgensi } \\
\text { Digitalisasi }\end{array}$ \\
\hline 1 & Registrasi Mahasiswa Baru & Belum & Sedang & Tinggi \\
2 & Administrasi Akademik & Sudah & Tinggi & Tinggi \\
3 & Kemahasiswaan & Sudah & Sedang & Sedang \\
4 & Penelitan dan Pengabdian Masyarakat & Belum & Sedang & Sedang \\
5 & Penjaminan Mutu & Belum & Tinggi & Rendah \\
6 & Kepegawaian & Sebagian & Rendah & Sedang \\
7 & Sarana Prasarana & Belum & Sedang & Rendah \\
8 & Administrasi Keuangan & Sudah & Tinggi & Tinggi \\
9 & Perpustakaan & Sebagian & Rendah & Rendah \\
\hline
\end{tabular}

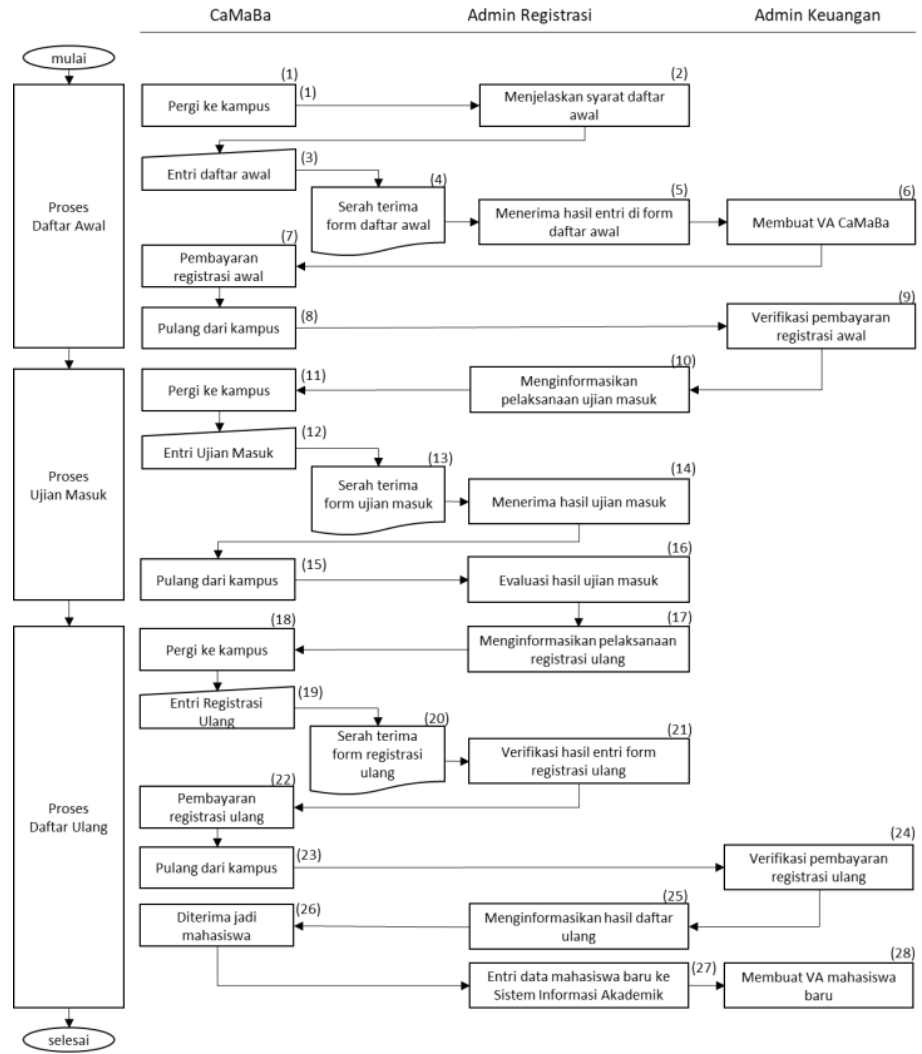

Gambar 1. As-Is process mapping tahapan registrasi mahasiswa baru

penciptaan Service Quality (SQ) yang unik dan unggul [5]. Sustainabilitas PT dapat tercapai apabila fokus dalam penyelenggaraan $S Q$ di semua bagian bisnis proses dari suatu PT [6].

Teknologi informasi yang semakin canggih di era revolusi industri 4.0 dapat menjadi perangkat yang membantu penciptaan SQ pada suatu PT. Beberapa publikasi sebelumnya [7]-[11] memanfaatkan teknologi informasi untuk digitalisasi bisnis proses dengan membuat Sistem Informasi Manajemen Perguruan Tinggi (SIMPT). Selain semakin banyak tersedianya platform open-source, era Revolusi Industri 4.0 juga semakin meningkatkan konektivitas antar sistem informasi dengan tersedianya teknologi
Application Programming Interface (API) yang membuat beberapa aplikasi dapat saling bertukar informasi. API adalah pusat dari banyak arsitektur perangkat lunak modern, karena menyediakan abstraksi tingkat tinggi yang memfasilitasi tugas pemrograman, mendukung desain aplikasi perangkat lunak terdistribusi dan modular, dan penggunaan kembali kode [12]-[14]. Pada era ini juga tentunya perlu strategi jitu khususnya dalam memenangkan persaingan penerimaan mahasiswa baru, diantaranya dengan implementasi digital marketing dan Sistem Informasi Registrasi Mahasiswa Baru (SIRMB) seperti yang dibahas oleh [15]. 
Tabel 2. Evaluasi PQCDSM

\begin{tabular}{|c|c|c|c|c|}
\hline Segmen & Parameter & Standar & Kondisi Sekarang & $\begin{array}{c}\text { Evalua } \\
\text { si }\end{array}$ \\
\hline \multirow[t]{2}{*}{ Productivity } & $\begin{array}{l}\text { - Pembuatan VA } \\
\text { - Lacak status daftar } \\
\text { - Waktu tunggu Admin } \\
\text { saat peserta entri } \\
\text { regitrasi }\end{array}$ & $\begin{array}{l}\text { - Otomatis } \\
\text { - Otomatis } \\
\text { - Tidak ada waktu } \\
\text { tunggu }\end{array}$ & $\begin{array}{l}\text { - Manual } \\
\text { - Manual } \\
\text { - Ada waktu tunggu }\end{array}$ & $\begin{array}{l}\text { NG } \\
N G \\
N G\end{array}$ \\
\hline & $\begin{array}{l}\text { - Evaluasi hasil ujian } \\
\text { masuk }\end{array}$ & - Otomatis & • Evaluasi manual & NG \\
\hline Quality & $\begin{array}{l}\text { - Admin entri data } \\
\text { pendaftar }\end{array}$ & - Tidak ada kesalahan & - Ada kesalahan & NG \\
\hline Cost & $\begin{array}{l}\text { - Form daftar awal } \\
\text { - Form daftar ulang } \\
\text { - Form ujian masuk } \\
\text { - Transportasi }\end{array}$ & $\begin{array}{l}\text { - Tidak ada biaya cetak } \\
\text { - Tidak ada biaya cetak } \\
\text { - Tidak ada biaya cetak } \\
\text { - Tidak butuh biaya }\end{array}$ & $\begin{array}{l}\text { - Ada biaya cetak } \\
\text { - Ada biaya cetak } \\
\text { - Ada biaya cetak } \\
\text { - Butuh biaya }\end{array}$ & $\begin{array}{l}\text { NG } \\
\text { NG } \\
\text { NG } \\
\text { NG }\end{array}$ \\
\hline Delivery & - Informasi status daftar & - Otomatis & $\begin{array}{l}\text { - Menunggu info } \\
\text { Admin }\end{array}$ & NG \\
\hline Safety & - Kecelakaan kerja & - Tidak ada kecelakaan & $\begin{array}{l}\text { - Tidak ada } \\
\text { kecelakaan }\end{array}$ & OK \\
\hline Morale & - Absensi Admin & $\begin{array}{l}\text { - Kehadiran sesuai } \\
\text { target }\end{array}$ & $\begin{array}{l}\text { - Kehadiran sesuai } \\
\text { target }\end{array}$ & OK \\
\hline
\end{tabular}

Catatan: NG (Not Good), OK (Good)

PMIC merupakan salah satu PT swasta berbentuk politeknik yang menyelenggarakan pendidikan vokasi di wilayah Cikarang, Jawa Barat. Tingginya tingkat persaingan PT di wilayah Jawa Barat, menuntut PMIC untuk terus berinovasi dan melaksanakan perbaikan dan proses digitalisasi berkesinambungan di semua proses bisnisnya. Dari hasil observasi, interview, dan brainstorming terdapat beberapa tahap proses bisnis yang dievaluasi menurut tingkat digitalisasi, faktor resiko, dan urgensi digitalisasi seperti yang ditampilkan pada Tabel 1. Berdasarkan prioritas pada tingkat urgensi digitalisasi yang tinggi untuk proses bisnis yang belum digitalisasi dan memiliki faktor resiko menengah ke tinggi, maka penelitian ini fokus pada proses bisnis registrasi mahasiswa baru.

Penelitian ini bertujuan untuk mengembangkan SIRMB dengan kerangka software open-source web-based application untuk perbaikan SQ dari permasalahan yang sudah diidentifikasi. Peneliti menggunakan metode analisis gugus kendali mutu (QCC) dengan pendekatan Plan-Do-Check-Action (PDCA) untuk memproses data, identifikasi permasalahan, serta merancang solusi SIRMB yang tepat. Metode QCC dengan pendekatan PDCA merupakan sistem manajemen perbaikan kualitas di industri yang sering digunakan di dalam penelitian sebelumnya oleh [16] dan penelitian lain di dalam referensinya. Selain itu, penelitian ini juga meningkatkan konektivitas
SIRMB sehingga terintegrasi dengan Sistem Informasi Akademik (SIA) yang sudah ada, serta terintegrasi juga dengan sistem API layanan keuangan perbankan untuk membentuk sistem administrasi terotomasi. Setelah implementasi SIRMB, terdapat perbaikan $76.9 \%$ dengan eliminasi proses kerja manual yang terdapat didalam as-is process mapping pada Gambar 1 sesuai dengan to-be process mapping pada Gambar 2, dan evaluasi PQCDSM memperlihatkan tujuan penelitian tercapai.

\section{METODE}

Penelitian ini dilaksanakan di PMIC yang merupakan industri jasa pendidikan untuk memecahkan permasalahan yang ada dengan metode analisis QCC menggunakan siklus PDCA yang terdiri dari delapan langkah dengan masing-masing langkah memiliki tools untuk membantu proses analisa dengan penjelasan kualitatif-deskriptif.

Delapan langkah QCC dengan siklus PDCA dijelaskan sebagai berikut [18]:

1. Menentukan Tema; Dalam langkah ini, dilakukan identifikasi permasalahan dengan metode observasi, interview, brainstorming, as-is process mapping, dan PQCDSM (productivity, quality, cost, delivery, safety, morale).

2. Menentukan Target; Langkah ini menentukan target berpedoman pada 
kriteria SMART (specific, measureable, achievable, reasonable).

Menentukan Tema

Tabel 3. Analisa Kondisi Yang Ada

\begin{tabular}{|c|c|c|c|c|c|}
\hline No & Faktor & Analisa & Kondisi Ideal & $\begin{array}{l}\text { Kondisi yang } \\
\text { Ada }\end{array}$ & $\begin{array}{c}\text { Evalua } \\
\text { si }\end{array}$ \\
\hline 1 & Man & - Admin registrasi & $\begin{array}{l}\text { - Bekerja sesuai } \\
\text { SOP }\end{array}$ & $\begin{array}{l}\text { - Bekerja } \\
\text { sesuai SOP }\end{array}$ & OK \\
\hline 2 & $\begin{array}{l}\text { Machine/ } \\
\text { Tools }\end{array}$ & $\begin{array}{l}\text { - Informasi syarat } \\
\text { registrasi } \\
\text { - Informasi status } \\
\text { registrasi } \\
\text { - VA untuk pembayaran }\end{array}$ & $\begin{array}{l}\text { - Tersedia online } \\
\text { - Tersedia online } \\
\text { - Terbuat otomatis }\end{array}$ & $\begin{array}{ll}\text { - Info } & \text { dari } \\
\text { Admin } & \\
- \text { Info } & \text { dari } \\
\text { Admin } & \\
\text { - Admin } & \text { buat } \\
\text { VA } & \end{array}$ & $\begin{array}{l}\text { NG } \\
\text { NG } \\
\text { NG }\end{array}$ \\
\hline 3 & Method & $\begin{array}{l}\text { - Metode registrasi } \\
\text { - Metode ujian masuk }\end{array}$ & $\begin{array}{l}\text { - Online } \\
\text { - Online }\end{array}$ & $\begin{array}{l}\text { - Offline } \\
\text { - Offline }\end{array}$ & $\begin{array}{l}\text { NG } \\
\text { NG }\end{array}$ \\
\hline 4 & Material & $\begin{array}{l}\text { - Formulir registrasi } \\
\text { - Formulir ujian masuk }\end{array}$ & $\begin{array}{l}\text { - Paperless } \\
\text { - Paperless }\end{array}$ & $\begin{array}{l}\text { - Paper-based } \\
\text { - Paper-based }\end{array}$ & $\begin{array}{l}\text { NG } \\
\text { NG }\end{array}$ \\
\hline 5 & Environme & - Tempat registrasi & - Tertib 5R & - Tertib 5R & OK \\
\hline
\end{tabular}

3. Analisa Kondisi; Pengumpulan data dan informasi untuk dianalisa berdasarkan 4M1E (man, machine, method, material, and environment) atau diagram tulang ikan.

4. Analisa Sebab Akibat; Berdasarkan faktafakta yang terjadi, dilakukan analisis penyebab terjadinya masalah dengan menggunakan diagram sebab-akibat dan 5Whys.

5. Rencana Penanggulangan; Rencana tindakan perbaikan dengan membuat to-be process mapping serta penjelasan rancangan dari SIRMB terintegrasi dengan Unified Modeling Languange (UML).

6. Penanggulangan; Pelaksanaan tindakan perbaikan yang sudah direncanakan.

7. Evaluasi Hasil; Penilaian terhadap keefektifan dan pencapaiannya terhadap target yang ditetapkan.

8. Standarisasi dan Tindak Lanjut; Hasil yang memenuhi target distandarisasi supaya masalah tidak berulang di kemudian hari.

QCC merupakan aktivitas grup untuk membahas dan menyelesaikan masalahmasalah dalam perbaikan kualitas dan penghematan biaya produksi secara teratur dan berkesinambungan [17]. Dalam pelaksanaan kegiatan, QCC memutar siklus Deming (PDCA) dan melakukan delapan langkah pemecahan masalah dengan tujuh alat bantu [16]. Dalam implementasinya, QCC dapat diterapkan pula pada industri jasa seperti pada penelitian yang dilakukan [18] berhasil menekan jumlah kehilangan gelas berukuran sedang sebanyak $60,10 \%$ dengan implementasi metode QCC di rumah sakit.

HASIL DAN PEMBAHASAN

Sesuai dengan pemilihan tema yang sudah dijelaskan, maka pada tahap awal dilakukan observasi, interview, dan brainstorming dengan tim marketing dan pihak terkait. Dari hasil tersebut, peneliti membuat asis process mapping sesuai dengan tahapantahapan registrasi mahasiswa baru yang ditunjukkan pada Gambar 1. Dan hasil evaluasi dengan metode PQCDSM ditunjukkan pada Tabel 2.

\section{Menentukan Target}

Berdasarkan hasil evaluasi PQCDSM, maka target ditentukan berdasarkan kriteria SMART sebagai berikut:

1. Specific (S), fokus untuk menghilangkan pekerjaan manual di dalam proses registrasi.

2. Measureable (M), fokus untuk menghilangkan biaya cetak formulir, biaya transportasi Calon Mahasiswa Baru (CaMaBa), waktu Admin membuat Virtual Account (VA), dan waktu tunggu Admin saat pengisian formulir di dalam proses registrasi.

3. Achievable (A), melalui pengembangan SIRMB terintegrasi dengan layanan keuangan perbankan.

4. Reasonable $(\mathrm{R})$, dapat tercapai dengan bantuan teknologi dan berdasarkan penelitian sebelumnya.

5. Timetable $(\mathrm{T})$, target tercapai di bulan Desember 2020.

Analisa Kondisi yang Ada

Pada tahap ini, peneliti melakukan analisa kondisi yang ada dengan metode 4M1E yang ditampilkan pada Tabel 3. Berdasarkan 
analisa kondisi yang ada ditemukan kondisi yang tidak sesuai dengan kondisi ideal pada faktor Machine, Method, dan Material.

\section{Analisa Sebab Akibat}

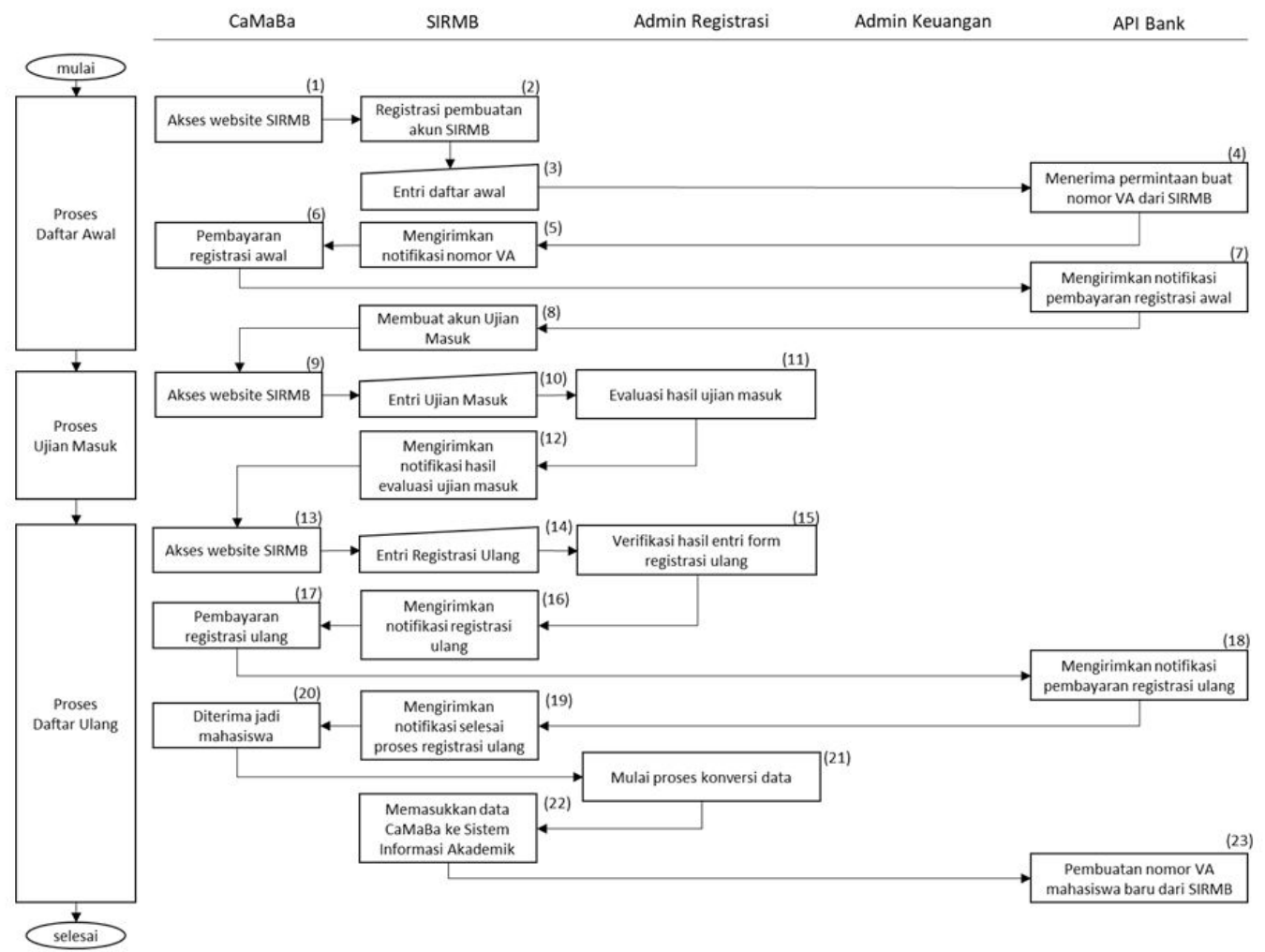

Gambar 2. To-be process mapping tahapan registrasi mahasiswa baru

Pada tahapan ini dilaksanakan analisa yang menyeluruh terhadap proses yang berlangsung. Penyebab dari ketidakidealan yang timbul pada analisa kondisi yang ada dapat disimpulkan sebagai berikut:

1. Tidak ada sistem informasi yang menyediakan,

a. Informasi syarat dan status registrasi.

b. Metode registrasi CaMaBa yang online.

c. Tempat entri data CaMaBa yang paperless.

d. Pendaftaran dan pelaksanaan Ujian Masuk dilaksanakan di tempat.

2. Tidak ada integrasi dengan sistem API yang menyediakan pembuatan VA Bank secara otomatis.

\section{Rencana Penanggulangan}

Peneliti merumuskan to-be process mapping untuk rencana penanggulangan yang menjelaskan sekuen atau flowchart dari bisnis proses setelah di-digitalisasi dengan pembuatan SIRMB terintegrasi yang ditunjukkan pada Gambar 2. CaMaBa hanya perlu akses website
SIRMB untuk melakukan registrasi sampai menjadi mahasiswa. Admin registrasi hanya melakukan tiga proses kerja manual, dan Admin keuangan tidak perlu melakukan proses kerja manual yang bersifat rutin untuk setiap 
Gambar 3. Sistem arsitektur SIRMB

Penanggulangan
Laravel. Implementasi SIRMB berjalan dari bulan Desember 2020. Gambar 5 menampilkan splash screen SIRMB. Tampilan utama setelah

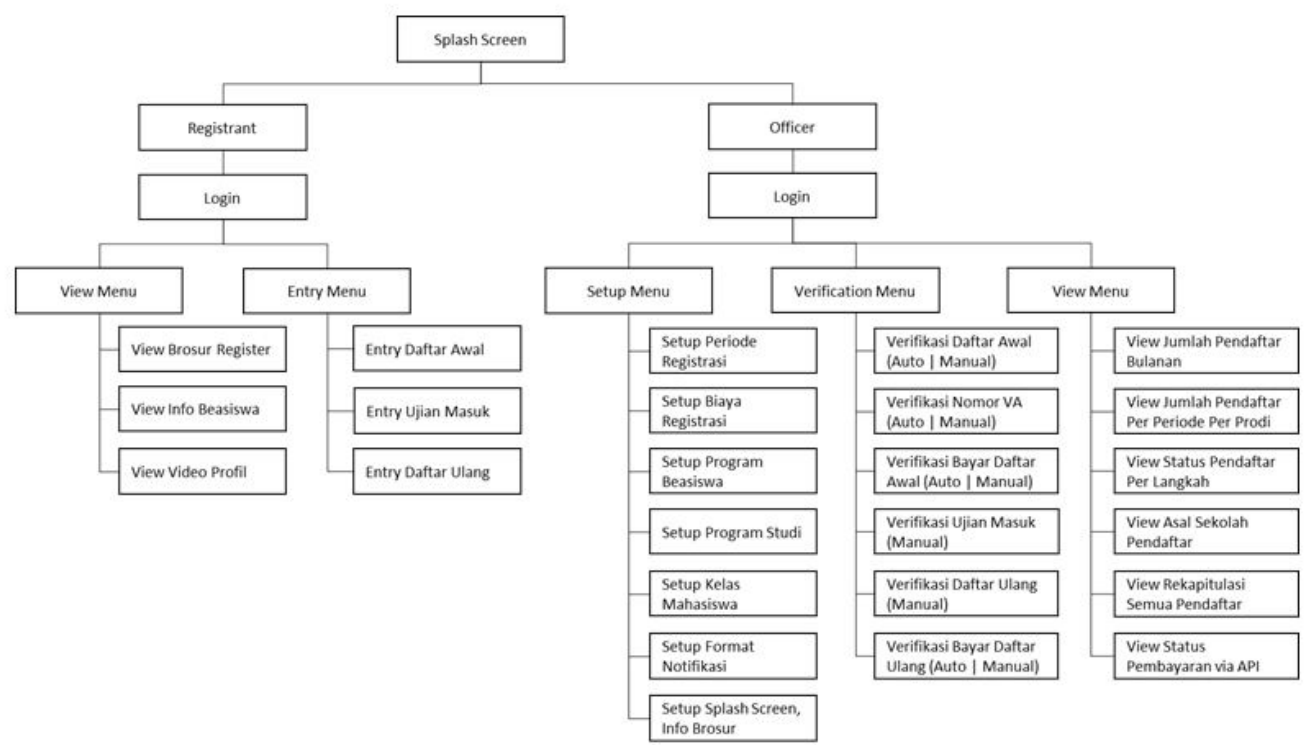

Gambar 4 Fitur menu aplikasi SIRMB

Sistem informasi merupakan sistem yang terdiri atas orang-orang, dan komputer yang dapat mengumpulkan, mengirimkan, menyimpan, memproses, memelihara, dan menggunakan informasi. Selain itu, dapat juga digunakan untuk memantau dan mengatur suatu operasi. Sistem informasi dapat menggunakan data masa lalu untuk memprediksi masa depan, membantu dalam pembuatan keputusan, dan pencapaian target [8]. Dari beberapa publikasi sebelumnya, pembuatan sistem informasi untuk PT menggunakan kerangka software yang bervariasi dan bersifat open-source, [10] mengembangkan sistem informasi mahasiswa berbasiskan mobile Android, [9] mengimplementasikan sistem arsitektur terdistribusi Arjuna, [8] membuat sistem registrasi mahasiswa baru berbasiskan web ASP.

Aplikasi sistem informasi berbasis web merupakan sebuah aplikasi yang diakses dengan menggunakan web browser melalui jaringan internet atau intranet. Aplikasi berbasis web modern menggunakan framework mempercepat proses pembuatan aplikasi. Framework mengintegrasikan bahasa pemrograman seperti PHP, HTML, CSS, dan Javascript. Laravel adalah salah satu framework dengan struktur MVC (Model, View, Controller) yang populer dan mempunyai banyak referensi di Internet [19].

Sistem informasi SIRMB dikembangkan berbasis web modern menggunakan framework login untuk menu $\mathrm{CaMaBa}$ seperti yang ditunjukkan Gambar 6. SIRMB memberikan fitur Lacak Status sehingga CaMaBa dapat secara langsung mengetahui status registrasinya. Terdapat tiga tahap dalam proses registrasi, yaitu: 1. Daftar Awal, 2. Ujian Masuk, 3. Daftar Ulang yang juga dapat diakses langsung dari tampilan utama. Gambar 7 menunjukkan tampilan menu daftar awal, setiap tahapnya ditampilkan secara sistematis sehingga memudahkan proses registrasi. SIRMB juga mempunyai fitur untuk Admin Registrasi mengirimkan notifikasi yang perlu ditindaklanjuti oleh CaMaBa seperti yang ditunjukkan Gambar 8.

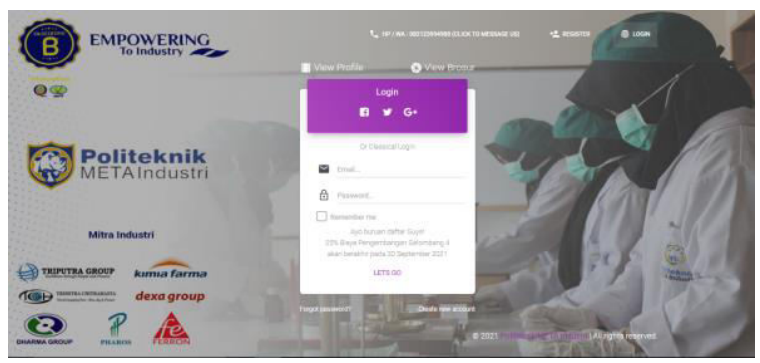

Gambar 5. Tampilan splash screen SIRMB 
Gambar 6. Tampilan menu utama SIRMB untuk CaMaBa

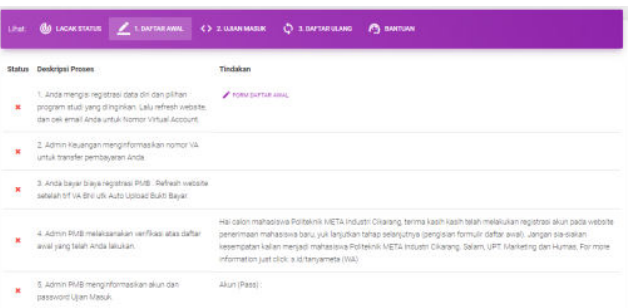

Gambar 7. Tampilan menu daftar awal SIRMB untuk $\mathrm{CaMaBa}$

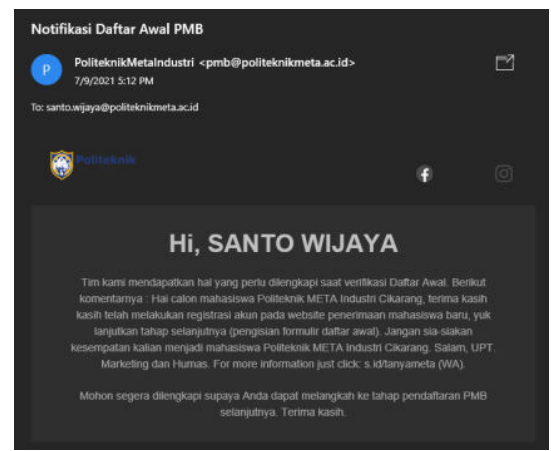

Gambar 8. Tampilan notifikasi email untuk $\mathrm{CaMaBa}$

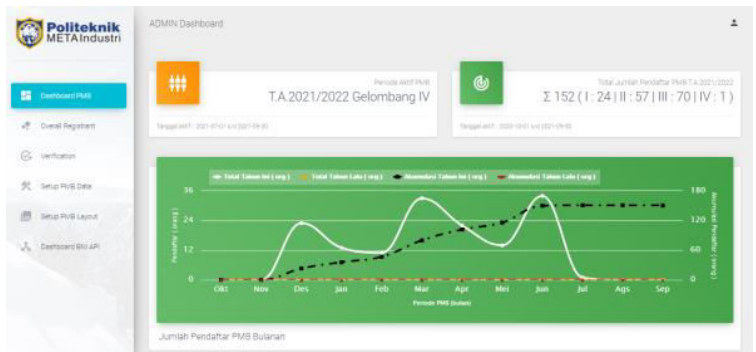

Gambar 9. Tampilan utama menu Admin SIRMB

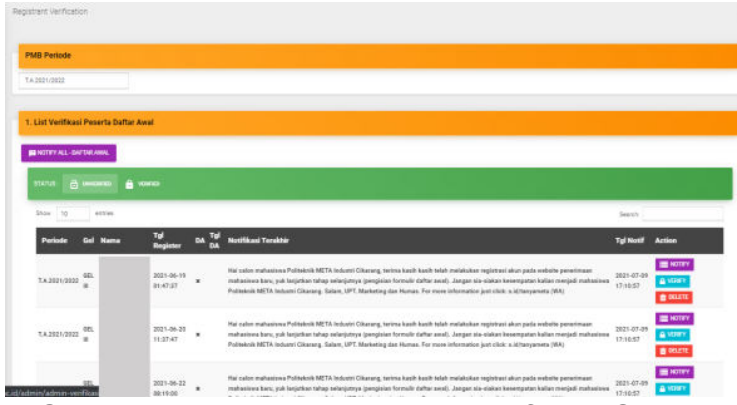

Gambar 10.Tampilan menu verifikasi SIRMB

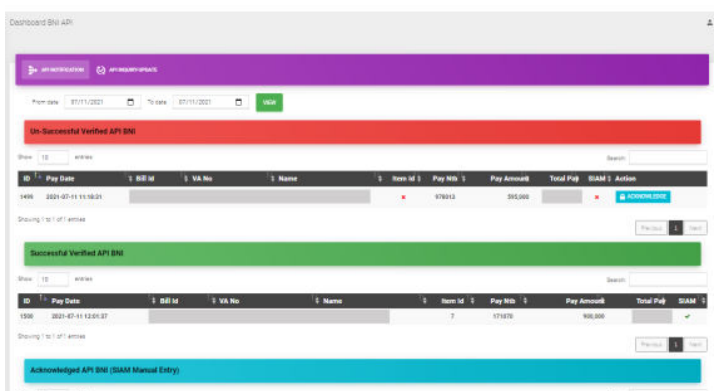

Gambar 11. Tampilan menu API Bank SIRMB

Tampilan utama SIRMB bagian Admin Registrasi dan Keuangan ditunjukkan pada Gambar 9. Bagian dashboard menampilkan laporan perkembangan registrasi mahasiswa baru. Gambar 10 menampilkan menu verifikasi SIRMB yang dikelompokkan menjadi enam tahap. Setiap tahap menampilkan informasi $\mathrm{CaMaBa}$ yang sudah diverifikasi dan yang belum terverifikasi untuk memudahkan pelacakan. Admin Registrasi dapat mengirimkan notifikasi per CaMaBa atau semua CaMaBa di dalam satu tahap jika diperlukan. Admin Keuangan melakukan kontrol terhadap status pembayaran melalui menu API Bank yang ditunjukkan Gambar 11. Jika terjadi kondisi abnormal, maka Admin Keuangan dapat melakukan intervensi dan melakukan entri secara manual ke sistem dan menginformasikan pihak Bank.

\section{Evaluasi Hasil}

Setelah implementasi penanggulangan, SIRMB berjalan sesuai to-be process mapping dan evaluasi PQCDSM ditampilkan pada Tabel 4. Evaluasi PQCDSM menunjukkan kondisi setelah perbaikan sesuai dengan standar atau tujuan yang telah ditetapkan di penelitian ini. Kemudian, SIRMB mengeliminasi sebelas dari tiga belas proses kerja manual yang dilakukan oleh Admin Registrasi dan Admin Keuangan yang terdapat pada Gambar 1, tetapi terdapat satu tambahan proses manual sesuai dengan Gambar 2. Sehingga tersisa tiga proses manual yang mesti dilakukan dengan tingkat perbaikan $76.9 \%$ terhadap proses kerja manual yang terdapat didalam process mapping. 
Sebelas proses manual sesuai Gambar 1 yang dieliminasi, yaitu: 1 . Menjelaskan syarat daftar awal (proses 2), 2. Menerima hasil lalu entri di form daftar awal (proses 5), 3. Membuat VA CaMaBa (proses 6), 4. Verifikasi pembayaran registrasi awal (proses 9), 5 . Menginformasikan pelaksanaan ujian masuk (proses 10), 6. Menerima hasil ujian masuk (proses 14), 7. Menginformasikan pelaksanaan registrasi ulang (proses 17), 8. Verifikasi pembayaran registrasi ulang (proses 24), 9. Menginformasikan hasil daftar ulang (proses 25), 10. Entri data mahasiswa baru ke Sistem Informasi Akademik (proses 27), 11. Membuat VA mahasiswa baru (proses 28).

Dua proses manual sesuai Gambar 1 yang masih dijalankan setelah implementasi aplikasi SIRMB, yaitu: 1. Evaluasi hasil ujian masuk (proses 16), 2. Verifikasi hasil entri form registrasi ulang (proses 21), yang menjadi proses 11 dan proses 15 pada Gambar 2. Tambahan satu proses manual sesuai Gambar 2 adalah mulai proses konversi data (proses 21). belum dihitung secara kuantitatif pada penelitian ini.

\section{Standarisasi dan Tindak Lanjut \\ Standarisasi setelah} perbaikan dilakukan dengan merevisi prosedur registrasi mahasiswa baru. Standarisasi meliputi manual penggunaan SIRMB, tindak lanjut Admin Registrasi dan Admin Keuangan saat terjadi kondisi abnormal pada aplikasi SIRMB, dan sosialisasi melalui iklan promosi tentang implementasi SIRMB untuk registrasi kepada masyarakat.

\section{KESIMPULAN}

Penelitian ini menghasilkan Sistem Informasi Registrasi Mahasiswa Baru (SIRMB) yang terintegrasi dengan layanan API keuangan perbankan. Penggunaan dan tampilan interface dibuat sesuai dengan alur proses yang dipetakan di dalam to-be process mapping, sehingga mudah untuk dioperasikan oleh CaMaBa, Admin Registrasi, dan Admin

Tabel 4. Evaluasi PQCDSM

\begin{tabular}{|c|c|c|c|c|}
\hline Segmen & Parameter & Standar & $\begin{array}{l}\text { Kondisi } \\
\text { Sekarang }\end{array}$ & $\begin{array}{l}\text { Setelah } \\
\text { Perbaikan }\end{array}$ \\
\hline $\begin{array}{l}\text { Productivit } \\
y\end{array}$ & $\begin{array}{l}\text { - Pembuatan VA } \\
\text { - Lacak status daftar } \\
\text { - Waktu tunggu } \\
\text { Admin saat } \\
\text { peserta entri } \\
\text { regitrasi } \\
\text { - Evaluasi hasil ujian } \\
\text { masuk }\end{array}$ & $\begin{array}{l}\text { - Otomatis } \\
\text { - Otomatis } \\
\text { - Tidak ada waktu } \\
\text { tunggu } \\
\text { - Otomatis }\end{array}$ & $\begin{array}{l}\text { - Manual } \\
\text { - Manual } \\
\text { - Ada waktu } \\
\text { tunggu } \\
\text { - Evaluasi } \\
\text { manual }\end{array}$ & $\begin{array}{l}\text { - Otomatis } \\
\text { - Otomatis } \\
\text { - Tidak ada waktu } \\
\text { tunggu } \\
\text { - Otomatis }\end{array}$ \\
\hline Quality & $\begin{array}{l}\text { - Admin entri data } \\
\text { pendaftar }\end{array}$ & $\begin{array}{l}\text { - Tidak ada } \\
\text { kesalahan }\end{array}$ & - Ada kesalahan & $\begin{array}{l}\text { - Tidak ada } \\
\text { kesalahan }\end{array}$ \\
\hline Cost & $\begin{array}{l}\text { - Form daftar awal } \\
\text { - Form daftar ulang } \\
\text { - Form ujian masuk } \\
\text { - Transportasi }\end{array}$ & $\begin{array}{l}\text { - Tidak ada biaya } \\
\text { cetak } \\
\text { - Tidak ada biaya } \\
\text { cetak } \\
\text { - Tidak ada biaya } \\
\text { cetak } \\
\text { - Tidak butuh } \\
\text { biaya } \\
\end{array}$ & $\begin{array}{l}\text { - Ada biaya } \\
\text { cetak } \\
\text { - Ada biaya } \\
\text { cetak } \\
\text { - Ada biaya } \\
\text { cetak } \\
\text { - Butuh biaya }\end{array}$ & $\begin{array}{l}\text { - Tidak ada biaya } \\
\text { cetak } \\
\text { - Tidak ada biaya } \\
\text { cetak } \\
\text { - Tidak ada biaya } \\
\text { cetak } \\
\text { - Tidak butuh } \\
\text { biaya }\end{array}$ \\
\hline Delivery & $\begin{array}{l}\text { - Informasi status } \\
\text { daftar }\end{array}$ & - Otomatis & $\begin{array}{l}\text { - Menunggu info } \\
\text { Admin }\end{array}$ & - Otomatis \\
\hline Safety & - Kecelakaan kerja & $\begin{array}{l}\text { - Tidak ada } \\
\text { kecelakaan }\end{array}$ & $\begin{array}{l}\text { - Tidak ada } \\
\text { kecelakaan }\end{array}$ & $\begin{array}{l}\text { - Tidak ada } \\
\text { kecelakaan }\end{array}$ \\
\hline Morale & - Absensi Admin & $\begin{array}{l}\text { - Kehadiran } \\
\text { sesuai target }\end{array}$ & $\begin{array}{l}\text { - Kehadiran } \\
\text { sesuai target }\end{array}$ & $\begin{array}{l}\text { - Kehadiran } \\
\text { sesuai target }\end{array}$ \\
\hline
\end{tabular}

Catatan: NG (Not Good), OK (Good)

Selain itu, terdapat penghematan biaya cetak formulir daftar awal, ujian masuk, dan daftar ulang setelah proses digitalisasi yang
Keuangan. Dengan implementasi SIRMB, maka terdapat perbaikan $76.9 \%$ terhadap proses kerja dengan eliminasi proses kerja manual yang dilakukan oleh Admin Registrasi dan Admin 
Keuangan di dalam bisnis proses registrasi mahasiswa baru. Selain itu, evaluasi PQCDSM juga menunjukkan hasil perbaikan yang sesuai dengan standar atau tujuan yang ditetapkan di dalam penelitian ini.

\section{REFERENSI}

[1] UU No.20 Tahun 2003, "Sistem Pendidikan Nasional." https://peraturan.bpk.go.id/Home/Details/ 43920/uu-no-20-tahun-2003 (accessed Jul. 08, 2021).

[2] LSP3I, "Pendidikan Tinggi: Industri Produk dan Jasa Berbasis IImu Pengetahuan."

https://yusrintosepu.wixsite.com/lsptigair egvsulawesi/single-

post/2017/02/09/pendidikan-industri-

produk-dan-jasa (accessed Jul. 08, 2021).

[3] PDDIKTI, "Pangkalan Data Pendidikan Tinggi." https://pddikti.kemdikbud.go.id/pt (accessed Jul. 08, 2021).

[4] M. Machfoedz, Pengantar Pemasaran Modern. Yogyakarta: UUP AMP YKPN, 2005.

[5] M. J. Widikusyanto and A. A. Hidayah, "Persaingan Industri Jasa Pendidikan Tinggi: Mengukur dan Meningkatkan Kualitas untuk Menciptakan Keunggulan Bersaing," Sains J. Manaj. dan Bisnis, vol. 11, no. 2, p. 200, 2019, doi: 10.35448/jmb.v11i2.6071.

[6] T. Thanh and T. Doan, "The Effect of Service Quality on Student Loyalty and Student Satisfaction: An Empirical Study of Universities in Vietnam," J. Asian Financ., vol. 8, no. 8, pp. 251-0258, 2021, doi: 10.13106/jafeb.2021.vol8.no8.0251.

[7] A. Noraziah, M. Syafiq Johari, T. Herawan, R. M. Sidek, H. C. Lee, and A. N. Abdalla, "Managing Registration of New Student Intake using ORNSISIntegrated Barcode Technology," in Procedia - Social and Behavioral Sciences, 2011, vol. 28, pp. 144-150, doi: 10.1016/j.sbspro.2011.11.029.

[8] Y. Liu, F. Gao, and Y. Liu, "Design and implementation of student registration system for universities," in 2nd International Conference on Consumer Electronics, Communications and Networks, 2012, no. 2, pp. 1760-1763, doi: 10.1109/CECNet.2012.6202263.

[9] M. C. Little, S. M. Wheater, D. B. Ingham, C. R. Snow, H. Whitfield, and S. K. Shrivastava, "The university student registration system: A case study in building a high-availability distributed application using general purpose components," Lect. Notes Comput. Sci., vol. 1752, pp. 453-471, 2000, doi: 10.1007/3-540-46475-1_19.

[10] T. Jamil and I. Mohammed, "Development of an Android-based Student Information System Application," in Future Technologies Conference, 2017, pp. 907-910.

[11] E. Shafie, K. Aldrawiesh, and A. Bajahzar, "Online Registration System," in 3rd IEEE International Conference on Advanced Computer Control (ICACC 2011), 2011, pp. 174-179.

[12] M. P. Robillard and R. Deline, "A field study of API learning obstacles," Empir. Softw. Eng., vol. 16, no. 6, pp. 703-732, 2011, doi: 10.1007/s10664-010-9150-8.

[13] J. Ofoeda, R. Boateng, and J. Effah, "Application Programming Interface (API) Research: A Review of the Past to Inform the Future," Int. J. Enterp. Inf. Syst., vol. 15, no. 3, pp. 76-95, 2019.

[14] F. Chen, L. Zhang, and X. Lian, "A systematic gray literature review: The technologies and concerns of microservice application programming interfaces," Softw. Pract. Exp., vol. 51, no. 7 , pp. 1483-1508, Jul. 2021, doi: 10.1002/SPE.2967.

[15] M. Ahmad, "Strategi penerimaan peserta didik baru pada era revolusi industri 4.0 melalui pemasaran jasa pendidikan di MI Salafiyah Margomulyo Kecamatan Kerek Kabupaten ...," 2020.

[16] S. Wijaya, G. Supriadi, F. Debora, and P. Y. D. Arliyanto, "Inhouse Quality Check System Improvement with Kanban System and Analysis Quality Control Circle," Oper. Excell., vol. 13, no. 1, pp. 22-35, 2021, doi: 10.22441/oe.2021.v13.i1.003.

[17] K. Khamaludin and A. P. Respati, "Implementasi Metode QCC untuk Menurunkan Jumlah Sisa Sampel Pengujian Compound," J. Optimasi Sist. Ind., vol. 18, no. 2, p. 176, 2019, doi: 10.25077/josi.v18.n2.p176-185.2019.

[18] Jonny, "Upaya Penurunan Kejadian Kehilangan Gelas Berukuran Sedang Melalui Penerapan Metode Quality Control Circle (QCC) di Unit Gizi, RS ABC, Jakarta," Comtech, vol. 3, no. 1, pp. 533-542, 2012, doi: https://doi.org/10.21512/comtech.v3il.245 2.

[19] M. Bean, Laravel 5 Essentials. 2015. 
ISSN 2089-8673 (Print) | ISSN 2548-4265 (Online)

Volume 10, Nomor 3, Desember 2021 